\title{
Ks. Franciszek SZULC, Syn Boży w „Pasterzu” Hermasa. Świadectwo chrys- tologii judeochrześcijańskiej. Studia Antiquitatis Christianae series nova 2, Katowice 2006, Księgarnia św. Jacka, ss. 198.
}

Fascynującą bez wątpienia rzeczą jest poszukiwanie najstarszych pokładów jakiegoś zagadnienia oraz odkrywanie jego zalążków i pierwszych sposobów jego formalnego wyrażania. Czyni to właśnie ks. dr Franciszek Szulc, który stawia sobie za zadanie odszukanie, w jakich kategoriach pojęciowych i językowych wyrażano wiarę w Jezusa jako Syna Bożego w najstarszej chrystologii judeochrześcijańskiej, obecnej w powstałym w 1. poł. II wieku wyjątkowo zagmatwanym myślowo i trudnym do interpretacji piśmie wczesnochrześcijańskim okresu Ojców Apostolskich Pasterzu Hermasa. W piśmie tym bowiem, zdaniem specjalistów, jest bardzo wyraźnie ukazana chrystologia judeochrześcijańska, a według naszego Autora zawiera ponadto „głębsze problemy dotąd nieujawnione, które nurtowały Hermasa i jego wspólnotę” (s. 14), zaś „w dotychczasowych publikacjach poświęconych bezpośrednio zawartej w nim chrystologii problem Syna Bożego nie został ani właściwie postawiony, ani wystarczająco wyjaśniony, natomiast w opracowaniach syntetycznych tego pisma problem ten nie został nawet zauważony" (s. 15). Analizując zaś nauczanie o Synu Bożym w Pasterzu Hermasa ks. dr F. Szulc chce również odpowiedzieć na cztery zasadnicze pytania: 1. z jakich źródeł inspiracji korzystał autor tego pisma; 2. w jakiej relacji pozostaje jego nauczanie do pism Nowego Testamentu; 3. w jakim stopniu na jego nauczanie wpłynął ówczesny kontekst historycznokulturowy; oraz 4. w czym wyraziła się własna twórczość Hermasa i jak należy oceniać jej wartość (s. 15), co zdaniem naszego Badacza da się sprowadzić do dwóch głównych zadań: rekonstrukcji najstarszej teologii Syna Bożego oraz wyjaśnienia genezy i charakteru Hermasowej koncepcji teologicznej.

Do rozwiązania tak określonego problemu, opracowanego w prezentowanej książce pt. Syn Boży w „Pasterzu” Hermasa. Świadectwo chrystologii judeochrześcijańskiej przygotowywał się nasz Autor poprzez swoje wcześniejsze 
publikacje: Obraz świata a zbawienie w teologii judeochrześcijańskiej, w: Teologiczne rozumienie zbawienia, red. Cz. Bartnik, Lublin 1979, 47-67; Wkład J. Daniélou do badań nad judeochrześcijaństwem, „Summarium” 29 (1980) 149-156; Spór o „Pasterza” Hermasa, VoxP 2 (1982) z. 3, 340-356; Struktura teologii judeochrześcijańskiej w świetle badań Jeana Daniélou, Lublin 1982, ss. 165 (rozprawa doktorska) i jej drugie wydanie poprawione i uzupełnione, Kraków 2005, ss. 221; Elkezaici, EK IV 898; Chrystologia „Pasterza” Hermasa jako problem badawczy, VoxP 6 (1986) z. 10, 117-135; Pierwotne znaczenie nauki o zstapieniu Chrystusa do otchtani $w$ świetle analizy historyczno-literackiej i hermeneutycznej, „Communio” 5 (1985) nr 1, 51-63; Hermas, autor „Pasterza”, EK VI 767-768; La théologie judéochrétienne: l'actualité de la conception de Jean Daniélou et l'assai de son développement, VoxP 24 (2004) t. 4647, 423-432, oraz 5 recenzji publikacji o tematyce judeochrześcijańskiej (a więc 14 na 50 publikacji Autora), które uczyniły z niego jednego z najlepszych polskich znawców teologii judeochrześcijańskiej. Ta zaś najstarsza teologia, odkryta na nowo i usystematyzowana 50 lat temu przez J. Daniélou, budzi i teraz coraz większe zainteresowanie i obfituje w coraz bogatszą literaturę (zob. m.in. S. Longosz, Judeochrześcijanie. Materiaty bibliograficzne, VoxP 21:2001, t. 40-41, 645-654; D.G. Horrell, Early Jewish Christianity, ed. Ph.F. Elser, London - New York 2004, ss. I 136-167).

Do rozwiązania postawionego problemu podszedł nasz Autor również po dobrym przyswojeniu sobie metodologii teologii pod kierunkiem znakomitego Księdza Profesora Cz. Bartnika, posługując się przy tym rzadko niestety stosowaną w teologii krytyką tekstu i strukturalno-semiotyczną analizą tekstu, z wykorzystaniem ingardenowskiej teorii dzieła literackiego i teorii gatunków literackich. Owocem tego rodzaju postępowania naukowego są znakomicie przeprowadzane w prezentowanej rozprawie obszerne analizy wybranych tekstów źródłowych oraz umiejętne porównywanie ich wyników z odpowiednią najnowszą, przeważnie obcojęzyczną, licznie cytowaną literaturą fachową, w której nasz Autor swobodnie się porusza, ocenia, krytykuje, chwali lub uzupełnia jej wyniki, proponując nierzadko swoje dojrzałe i uzasadnione rozwiązania. W swoich dociekaniach nie unika też analiz czysto filologicznych kluczowych tekstów źródłowych, suponujących dobrą znajomość ich oryginalnego języka greckiego, których ważniejsze partie przy cytowanych tłumaczonych fragmentach przytacza często w nawiasach po grecku.

Swoje poszukiwania języka i sposobu wyrażania wiary w Jezusa jako Syna Bożego w najstarszej teologii judeochrześcijańskiej, obecnej w Pasterzu Hermasa, ujmuje nasz Autor w rozprawie zbudowanej z czterech rozdziałów, lub jak je sam nazywa (s. 16) „,czterech bloków zagadnień”, poprzedzonych spisem treści w języku polskim i francuskim oraz wykazem skrótów i wprowadzeniem, a zakończonych podsumowaniem, bibliografią i obszernym Résume w języku francuskim (ss. 190-198). We wprowadzeniu uderza czytelnika brak tradycyj- 
nego status quaestionis z omówieniem najnowszych badań nad najstarszą chrystologią (zwłaszcza obecną w Pasterzu Hermasa), bo nasz Autor prezentuje go szczegółowo (chyba z większym pożytkiem) na początku każdego rozdziału z wyjaśnieniem terminów oraz z podaniem historii badanego problemu i metodycznego instrumentarium. Brak jest w nim również szczegółowego omówienia badanego źródła, ale Autor nasz poświęca temu zagadnieniu z przekonywującym uzasadnieniem cały rozdział I. Każdy zresztą rozdział rozprawy ma na swym początku jasno postawiony problem (najczęściej w formie pytania) oraz plan jego rozwiązania, a na końcu zebranie wynikających z analizy, wniosków wraz z próbą ich oceny.

Pozornie zbyteczny i podający, zdawać by się mogło, podręcznikowe informacje rozdział I rozprawy pt. „Pasterz w świetle krytyki historyczno-literackiej” (ss. 17-67) jest faktycznie obszernym szczegółowym wprowadzeniem, w którym Autor, w oparciu o zebrane zewsząd informacje, określa po swojemu charakter analizowanego dzieła, jego strukturę, gatunek literacki, jego autorstwo, czas powstania i adresatów oraz zawarte w nim ważniejsze wyrażenia, co w konsekwencji ma ułatwić jego późniejszą interpretację. Informuje więc czytelnika (chyba mimo wszystko za obszernie i zbyt szczegółowo przy tym charakterze rozprawy) o manuskryptach, języku i XX-wiecznych krytycznych wydaniach tekstu, stwierdzając, że mimo znanej przez wieki tylko wersji łacińskiej, językiem oryginalnym tego dzieła jest język grecki, poświadczony w kodeksach z Góry Athos, Synaju i Michigan (Codex Athensis z XV w. odkryty w 1855, Codex Sinaiticus z IV w. odkryty w 1859 r., Michigan Codices z końca II i III w. odkryte w 1922 r.) zaznaczając, ,że taką ilością starożytnych manuskryptów, jaką posiada Pasterz Hermasa, nie może się poszczycić żadne z dzieł Ojców Kościoła [...] a zarazem tak wczesnego przekładu” (s. 18 i 22), co świadczy o jego dużej popularności (zachowały się dwie starożytne wersje koptyjskie oraz etiopska i perska) dodając, że mimo istnienia z trzech dobrych opublikowanych ostatnio wydań krytycznych: M. Whittakera (GCS 48, Berlin 1957), R. Joly'ego (SCh 53, Paris 1968) i M. Leutzscha (Darmstadt 1998) on sam będzie się posługiwał tym ostatnim konsultując dwa poprzednie, oraz najnowszym polskim przekładem A. Świderkówny (BOK 10, Warszawa 1998, ss. 211-291). Przy ustalaniu struktury dzieła Autor nasz zaznacza, że chce się posługiwać metodologią wypracowaną na gruncie teorii literatury - analizą strukturalnosemiotyczną tekstu (s. 22) i zamiast tradycyjnego podziału tekstu Pasterza na 5 wizji (Vis), 12 przykazań (Mand) i 10 przypowieści (Sim), on przyjmuje swój podział na 4 następujące po sobie sekwencje: 1. Vis I-IV; 2. Vis V-Sim VIII; 3. Sim IX; 4. Sim X: w tej bowiem kolejności i z tych części, jego zdaniem, tekst ten został zredagowany bądź przez samego autora, bądź przez ostatecznego redaktora, który wykorzystał wcześniej spisane tradycje. Ten też podział tekstu będzie wpływał, zdaniem naszego Autora, na sposób interpretacji tego pisma, która mu zapewni jego zrozumienie. Stąd też ,wszelkie analizy semantyczne, tematyczne 
czy doktrynalne winny być przeprowadzane najpierw w obrębie wyróżnionych już jednostek makrotekstowych, a następnie dopiero można dokonywać porównań uzyskanych wyników, wraz z ich interpretacją, w odniesieniu do całego dzieła" (s. 25). Jest to bez wątpienia nowe i w dużej mierze oryginalne spojrzenie naszego Autora na tekst Pasterza Hermasa, choć niektóre jego wątki były wcześniej sugerowane przez N. Broxa (Der Hirt des Hermas, Göttingen 1991) i Ph. Henne'go (L'unité du Pasteur d'Hermas, Paris 1992).

W nowy też sposób określa nasz Autor gatunek literacki Pasterza (ss. 2532). Najpierw przytacza i omawia kilka (6) współczesnych prób określenia gatunku tego dzieła, jak np. że jest to „pseudoapokalipsa” (Ph. Vielhauer), zbiór lub „księga alegorii (N. Brox), dzieło o charakterze etycznym z domieszką różnych gatunków (J.Ch. Wilson), produkt literacki sui generis - zaliczany do kategorii wczesnochrześcijańskich listów do wspólnoty (A. Schneider), lub katecheza o tematyce pokutnej (M. Simonetti). W odpowiedzi na te określenia nasz Autor bez szerszego uzasadnienia stwierdza: „definiujemy Pasterza jako odmianę gatunkową wczesnochrześcijańskiej apokaliptyki” (s. 32), co, jego zdaniem, potwierdza tematyka tego pisma i świat $\mathrm{w}$ nim przedstawiony. W związku z tym rodzi się pytanie: co to jest wczesnochrześcijańska apokaliptyka oraz jaka jest geneza i cechy tego gatunku literackiego, bo w książce brak na to odpowiedzi i obszerniejszego wyjaśnienia?

W dalszej części tego rozdziału Autor nasz przybliża szczegółowo tematykę Pasterza (ss. 32-67) analizując po kolei z „zastosowaniem współczesnych osiągnięć krytyki tematycznej, genologii oraz teorii dzieła literackiego" (s. 169) wyodrębnione przez siebie 4 jego części i odnotowując przy tym skrzętnie wszystkie miejsca (z przytoczeniem tekstów), w których występują istotne dla postawionego problemu terminy: „Syn” (ó viós) i „Syn Boży” (ó viós toṽ

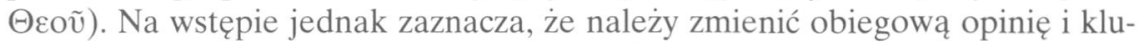
czowych dla tego dzieła terminów $\mu \varepsilon \tau \alpha v o \varepsilon ́ \omega-\mu \varepsilon \tau \alpha ́ v o ı \alpha$ nie tłumaczyć ,„pokutować" - ,pokuta”, jak to powszechnie błędnie czyniono do poł. XX wieku, ale „nawrócić się” - „nawrócenie” (tak m.in. A. Suski, T.M. Dąbek), bo pismo to nie jest w żadnym wypadku traktatem o pokucie, ale jak to sugerują niektórzy współcześni badacze (S. Giet, Ph. Henne), osobowym i społecznym, skierowanym do całego Kościoła wezwaniem do nawrócenia i wieloaspektowej odnowy moralnej: „uważam że termin «pokuta», ani nawet szerszy od niego termin «nawrócenie» nie oddają w pełni specyfiki i dominanty treściowej tego pisma. Dlatego proponuję, rozszerzyć te tradycyjne określenia i przyjąć, że tematem głównym Pasterza jest program odnowy moralnej Kościoła w wymiarze osobowym i społecznym" (s. 52).

Pod koniec rozdziału ks. dr F. Szulc próbuje ustalić autorstwo, miejsce, czas powstania i adresatów Pasterza (ss. 52-67) przytaczając i oceniając poglądy na ten temat wielu badaczy od poł. XIX wieku (C. de Champagny, J. Haussleiter, A. Hilgenfeld, A. Harnack, Th. Zahn, F. Spitt, M. Dibellius, E. Joly, S. Giet, 
J. Daniélou, A. Hilhorst, W. Coleborne, N. Brox, Th. Henne, J.Ch. Wilson, A.C. Sudberg, M. Leutzsch), by stwierdzić, ,że Pasterz z całą pewnością nie powstał później niż w połowie II wieku, natomiast nie można wykluczyć, że mógł powstać znacznie wcześniej” (s. 64). Nie da się natomiast jednoznacznie ustalić, kto konkretnie jest autorem Pasterza, ale idąc za kryteriami współczesnej teorii literatury, ks. dr F. Szulc odróżnia: 1. Hermasa jako umownego autora (redaktora), 2. Hermasa narratora, który może być odautorskim interpretatorem, oraz 3. Hermasa - bohatera wewnątrz tekstu, który jest kreacją literacką (s. 67). Pismo to powstało w Rzymie, a jego potencjalnymi adresatami są wszyscy w Kościele. Celowo tak szczegółowo przybliżyłem treść tego I, pozornie nie związanego z tematyką rozprawy, by ukazać nowe literackie podejście naszego Autora do postawionego problemu, jego erudycję, oraz nierzadko jego oryginalne i odważne sądy, co niewątpliwie rzutować będzie w sumie na dalszą interpretację badanego zagadnienia.

W równie obszernym rozdziale II pt. „Syn Boży w postaci anioła” (ss. 68113) Autor nasz przechodzi już do właściwego tematu nawiązując do najstarszej formy chrystologii, zwłaszcza heterodoksyjnej chrystologii judeochrześcijańskiej, w której Chrystusa identyfikowano z aniołem (= chrystologia angelomorficzna, Engelchristologie), i pytając, czy to zjawisko zachodzi również w Pasterzu Hermasa, czyli, czy w tym piśmie można również stwierdzić obecność chrystologii angelomorficznej. Tym właśnie dyskusyjnym i frapującym tematem zajmują się badacze od ponad 100 lat. Autor nasz prezentuje najpierw przegląd poglądów kilkunastu z tych badaczy (W. Leuken, M. Werner, C. Barbel, G. Kretschmar, J. Daniélou, S. Giet, R.L. Longenecker, A. Grillmeier, H. Moxnes, R. Lorenz, J. Fossum, Ph. Henne, N. Brox, Ch.A. Gieschen), którzy na ten temat różnorodnie, często rozbieżnie się wypowiadali, ocenia je i często zasadnie krytykuje, a następnie poddaje analizie wszystkie główne miejsca (np. Vis 5, 2; Mand V 1, 7; Sim VII; Sim IV 4, 4; Sim VIII i IX), w których występują różnie nazwane postacie anielskie ze wskazaniem ich funkcji (np. Anioł chwalebny, anioł Michał, Anioł Boga, młodzieniec, Anioł pokuty, Anioł najczcigodniejszy, Anioł Pana), respektując przy tym założony podział i rozwój tekstu, by głównie w oparciu o przebadane teksty zauważyć (m.in. wbrew zdaniu J. Daniélou), że ,nie można zasadnie stwierdzić, że autor Pasterza uważał Syna Bożego za anioła i w tym znaczeniu nie może być mowy o chrystologii angelomorficznej" (s. 112). Owszem, sam autor Pasterza używał, zdaniem naszego Autora, mocnych środków i argumentów, aby Syna Bożego nie uważać za jednego z aniołów, co było rozpowszechnione w judeochrześcijaństwie: Syn, jak wskazują pewne miejsca tekstu, jest doradcą Boga i góruje swoją godnością i władzą nad całym stworzeniem (Vis II), wykazuje zbawczą aktywność (Sim V i VII), a nawet jest w nich mowa (Sim IX) o Jego preegzystencji i odwiecznym zrodzeniu, natomiast Kościół i aniołowie są tylko stworzeniami. Autor Pasterza, zdaniem ks. dra F. Szulca, przyjmuje, że czytelnik 
judeochrześcijański, obeznany ze światem angelologii żydowskiej, z językiem teofanii Starego i Nowego Testamentu i bogatej literatury międzytestamentalnej, łatwo zrozumie, że Syn Boży może się również objawiać pod postacią anioła. I w tym wypadku jest to bez wątpienia nowe i odważne stwierdzenie naszego Autora, zdające się być w dokonanych analizach tekstu uzasadnione, przeciwne większości znanych badaczy chrystologii judeochrześcijańskiej, na pozycję Syna Bożego w Pasterzu Hermasa. Można tu jednak postawić pytanie Autorowi: za ważne świadectwo judeochrześcijańskiej chrystologii angelomorficznej uważa się powszechnie, obok Pasterza Hermasa, również apokryf Wniebowstapienie Izajasza, gdzie m.in. występuje przewyższająca wszystkich chwałą postać, która przemienia się i staje jednym z aniołów $(9,27-30)$. Zazwyczaj prawie wszyscy badacze chrystologii judeochrześcijańskiej (m.in. M. Simonetti, Cristologia Giudeocristiana: caratteri e limiti, „Augustinianum” 27:1988, 51-69; Ch.A. Gieschen, Angelomorphic christology, Leiden 1998, 229-244; D.D. Hannach, The Ascension of Isaiah and docetic christology, „Vigiliae Christianae" 53:1999, 165-196) uwzględniają i komentują to źródło mówiąc niekiedy o występującej w nim chrystologii doketycznej, nasz Autor natomiast, nie wiadomo z jakich powodów, przemilcza je całkowicie, nie komentując go, ani nie wymieniając go nawet wśród źródeł w bibliografii: jakie więc znaczenie ma ten apokryf dla chrystologii angelomorficznej i czy ona ma w nim faktycznie charakter doketyczny? - wypadałoby to wyjaśnić.

W kolejnym, nieco już krótszym III rozdziale rozprawy pt. „Sługa wyniesiony do godności Syna Bożego" (ss. 114-151) ks. dr F. Szulc podejmuje próbę wyjaśnienia genezy i określenia tożsamości doktrynalnej koncepcji Syna Bożego, przedstawionej w V przypowieści ( $\operatorname{Sim} \mathrm{V}$ ), gdzie autor Pasterza wypowiada się wprost na Jego temat. Nie zaprezentował on jednak w niej swoich wypowiedzi w sposób jasny i koherentny, ale stanowią one zbiór różnych obrazów, dociekań i orzeczeń, które w sumie tworzą bardzo specyficzną teologię Syna Bożego. Najpierw jednak nasz Badacz starając się odpowiedzieć na pytanie, dlaczego i na jakiej podstawie Duch Święty został tu nazwany Synem, czyli w jakim sensie można mówić o chrystologii pneumatologicznej (Geistchristologie, pneumatische Christologie) w Pasterzu Hermasa, prezentuje całą gamę wypowiedzi znawców chrystologii judeochrześcijańskiej od końca XIX wieku (A. Harnack, R. Seeberg, F. Loofs, M. Dibellius, M. Simonetti, L. Cirillo, L.W. Nijendijk, Ph. Henne, N. Brox, A. Stewart-Sykes, R.J. Hauck) na ten temat, potem dzieli V przypowieść na dwie zasadnicze części (V 1, 1 - 3, 9 i V 4,1 - 7, 4) wydzielając w nich 8 cząstek, by na nich zdanie po zdaniu dokonać solidnej i głębokiej analizy tematycznej, opartej na trzech wyjaśnieniach przypowieści (Sim V 5, 1-4; V 6, 1-4a; V 6, 4b-7a). Na początku pierwszego wyjaśnienia zaskakuje zdanie: „Synem jest Duch Święty, a niewolnik jest Synem Bożym” (Sim V 5, 2), co w teologicznej koncepcji Hermasa można wyrazić: „Duch Święty jest Synem, a Sługa jest Synem Bożym”. Nasz Autor stwierdza, że 
„Hermas stworzył zupełnie nową interpretację tytułu «Syn Boży», (s. 151), na Hermasową zaś teologię Syna Bożego składają się 4 zasadnicze komponenty (s. 150, 174): 1. koncepcja „wybranego ciała”, w którym zamieszkał Duch Święty

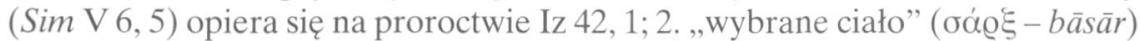
to Ebed Jahwe - „Wybrany Boga”; 3. Duch Święty to Ruah Jahwe, który nie tylko „spoczął” na Słudze, ale w Nim ,zamieszkał”. Doktryna o Duchu Świętym posiada proweniencję starotestamentalno-judaistyczną, zaś idee Syna-Ducha Świętego zaczerpnął Hermas z rabinistycznych spekulacji nad be'rešit (,początek” - „Syn” z Rdz 1, 1, które były znane judeochrześcijanom; 4. przez „zamieszkanie” Syna-Ducha Świętego w „wybranym ciele”, czyli w Słudze Bożym (Jezusie), został on wyniesiony do godności Syna Bożego i odtąd ten tytuł przysługuje tylko Jemu. Hermas połączył tu w sposób twórczy wiarę monoteistyczną z wiarą w Sługę Bożego - Jezusa, w którym Bóg spełnił swoje zbawcze obietnice wobec swego ludu. On to przez zamieszkanie Ducha Świętego-Ducha Boskości otrzymał od Boga godność i tytuł Syna Bożego.

Do powyższych przedstawionych w skrócie konstatacji teologicznych o Synu Bozym w Pasterzu Hermasa doszedł nasz Autor po szczegółowej, obszernej i solidnej analizie $\mathrm{V}$ jego przypowieści (co należy wysoko ocenić) i porównywania jej wyników z odpowiednią literaturą na ten temat. Ciekawą rzeczą jest również zwrócenie uwagi przez naszego Autora (s. 145) na mało znaną rabinistyczną interpretację be'rešit z Rdz 1, 1, tłumaczonego jako ,początek” - „syn”, przyjętą później przez najstarszych egzegetów chrześcijańskich (Aryston z Pelli, Justyn, Ireneusz, Tertulian, Hilary z Poitiers), której również można by poświęcić więcej miejsca.

Wreszcie w najkrótszym IV rozdziale rozprawy pt. „Imię Syna Bożego” (ss. 152-168) Autor nasz stara się odczytać rzadko badany problem znaczenia i funkcji Imienia Syna Bożego w Pasterzu Hermasa, które stanowią istotny i bogaty w swej treści składnik jego teologii o Synu Bożym. Aby ją w pełni odkryć i ukazać prezentuje znów tradycyjnie najpierw poglądy kilkunastu współczesnych starających się wyświetlić ten problem w pismach Starego i Nowego Testamentu, a następnie kilku zaledwie badaczy (J. Daniélou, F.J. Untergassmair, A. Grillmeier, J.E. Fossum) ukazujących rozwój i znaczenie onoma-chrystologii w literaturze wczesnochrześcijańskiej, zwłaszcza w Pasterzu Hermasa. $\mathrm{Z}$ ich przeglądu wynika, że brak dotąd całościowego opracowania teologii Imienia Syna Bożego w tym dziele. Zatem przez własną i chyba najbardziej twórczą w całej rozprawie analizę dobranych tekstów z tego dzieła stara się zrekonstruować Hermasową teologię Imienia Syna Bożego, określając najpierw jego semantyczne pole, potem jego przymioty i funkcje, a wreszcie postawę wierzących wobec Niego, wyrażającą się w przyjęciu i noszeniu tego Imienia, w gotowości cierpienia $\mathrm{z}$ Jego powodu oraz w głoszeniu Go i propagowaniu: wszystkie te myśli poparte są odpowiednio dobranymi tekstami. Najpierw analiza pola semantycznego Imienia prowadzi, zdaniem naszego Autora, do wniosku, że w Vis 
I-IV Hermas używa określeń „Imię Boga”, „Imię Pana” w typowo żydowskim „znaczeniu, a w Sim IX posługuje się formułą „Imię Syna Bożego” lub „Imię” w znaczeniu przez siebie ustalonym, w odróżnieniu jednak od Nowego Testamentu, gdzie "Imię" łączy się najczęściej z imieniem własnym (Jezus), to w Pasterzu wskazuje Ono na pełnione przez Syna Bożego funkcje, służąc przy tym do charakteryzowania różnych postaw wiernych wobec Niego. „Imię” w Pasterzu jest często używane jako hipostaza Syna Bożego, a Jego imię własne pozostaje zakryte, podobnie jak w tradycji żydowskiej. „Przyjąć” Imię Syna Bożego jest synonimem chrztu, a „nosić” Imię oznacza przyjąć i realizować wszystkie wymagania etyczne, stawiane przez wiarę. Wiele miejsca poświęcił Hermas cierpiącym z powodu Imienia, zarówno męczennikom przebywającym w chwale, jak i aktualnym członkom wspólnoty kościelnej. Najważniejszym zadaniem apostołów było głoszenie Imienia Syna Bożego, które daje życie i zapewnia zbawienie. Streszczone wyżej krótko myśli o Imieniu Syna Bożego pozwalają naszemu Autorowi stwierdzić, że „Hermas stworzył najbardziej oryginalną i rozwiniętą teologię Imienia Syna Bożego w pierwotnym chrześcijaństwie" (s. 176). Ja zaś ze swej strony uważam, a zapewne niejeden badacz teologii Imienia Bożego zgodzi się ze mną, że powyższe uwagi ks. dra F. Szulca o Imieniu Syna Bożego w Pasterzu Hermasa stanowią oryginalny, ważny i cenny przyczynek do studiów nad teologią Imienia Bożego w patrystyce.

Jeśli zaś chodzi o całość nauki o Synu Bożym w Pasterzu Hermasa, to ks. dr F. Szulc stwierdza, że ma ona charakter judeochrześcijański, ale jego autor nie bazuje całkowicie na chrystologii judeochrześcijańskiej (angelomorficznej, pneumatologicznej, nomologicznej i onomatologicznej), ale tylko twórczo ją wykorzystuje do własnej syntezy teologicznej tworząc taką naukę o Synu Bożym, jaką mogli zrozumieć i akceptować zarówno Żydzi, jak i chrześcijanie tamtych czasów: i to było jego najważniejszym osiągnięciem.

Spoglądając całościowo na rozprawę habilitacyjną ks. dra F. Szulca trzeba stwierdzić, że jest ona metodologicznie wyjątkowo starannie dopracowana, o jasnej i przejrzystej strukturze, prawie że bez błędów literowych (znalazłem tylko kilka np. s. 15, n. 9: „Bibel und Chritologie” zamiast: Christologie; s. 59, n. 149: „Shephard of Hermas: A Cose for a multiple” zamiast: Case for a multiple; s. 73 drugi cytat od góry: xóøuoo zamiast: xóøuos; s. 139, n. 64: „Die Pneumatologie des Hiten" zamiast: Hirten), ze znakomicie dopracowanymi przypisami, w których do własnych wyników dołącza odpowiednio dobraną przeważnie obcojęzyczną literaturę, z uzasadnionymi poprawkami polskich (zwłaszcza A. Świderkówny) lub obcych przekładów źródeł (np. s. 83, n. 54; s. 34, n. 56; ss. 105106, n. 114), z odważnymi krytycznymi, ale uzasadnionymi ocenami poglądów nawet wielkich badaczy (np. J. Daniélou), z częstym przytaczaniem źródeł w ich greckim języku oryginalnym i ze znakomicie przeprowadzanymi ich analizami. 